\title{
14 ATURAN SURVIVE UNTUK BISNIS STARTUP
}

\author{
Agung Purnomo \\ Institut Teknologi Kreatif Bina Nusantara Malang \\ agung.purnomo@binus.ac.id
}

\section{Pendahuluan}

Proses bisnis bagi bisnis startup atau pemula laksana pertempuran di medan perang. Ketika perjalanan impian membangun bisnis startup anda terasa semakin berat, bisa jadi karena anda: a) melupakan atau tidak tahu semua aturan dan pengetahuan yang dibutuhkan agar bisnis startup anda tetap survive atau selamat bertahan hidup, atau b) melupakan pelajaran bisnis yang mengantar anda sampai di tahapan sekarang.

Jika Anda belum dapat mengingat apa pun pelajaran bisnis yang telah Anda pelajari, ada satu aturan yang akan menyelamatkan Anda, yaitu memahami konsumenatau pengguna dari jasa atau produk bisnis Anda. Konsumenlah yang membuat bisnis Anda tetap bertahan hidup. Sebuah bisnis startup yang bermanfaat untuk konsumen tidak akan mati, paling tidak dari faktor penyebab eksternal.

\section{Aturan Survive untuk Bisnis Startup}

1. Banyak berdoa

Perbanyak berdoa dan dekatkan diri anda kepada Tuhan YME agar bisnis anda lancar dan berhasil. Banyak faktor dan elemen di bisnis yang diluar kuasa dan rencana kita. Tentunya, bisnis akan lebih bermakna jika kita menjalaninya sebagai ibadah bukti ketaatan kita kepada Tuhan YME.

\section{Pilih co-founder yang baik}

Sesuatu yang paling sering membunuh sebagian besar bisnis startup adalah ya tim startup itu sendiri. Semua masalah berawal dari menemukan cofounderatau rekan pendiri bisnis yang buruk. Co-founder buruk bisa jadi orang yang sangat baik secara sosial. Mereka mungkin tidak melakukan peran meraka dengan baik di startup untuk alasan yang tidak jahat, seperti kembali ke sekolah, sambil kerja, atau bahkan memiliki proyek bisnis sampingan. Itu sebabnya cukup sulit untuk menentukan siapa yang akan menjadi co-founder yang baik di periode awal. 


\section{Luncurkan cepat}

Sampai Anda memulai, pengguna atau konsumen tidak dapat menggunakan jasa atau produk karya Anda. Jika pengguna tidak dapat menggunakan Anda, startup Anda tidak berguna bagi mereka. Semakin lama Anda tetap seperti itu, semakin sulit akan untuk menghentikan kebiasaan itu. Peluncuran sebelum Anda terbiasa untuk tidak menjadi berguna. Juga, untuk menguji apakah bisnis anda memang dibutuhkan oleh pengguna. Jangan-jangan anda merasa bisnis anda penting dan berguna bagi konsumen, padahal konsumen berpendapat sebaliknya. Lakukan Minimum Viable Product (MVP) segera.

\section{Biarkan ide Anda berkembang}

Banyak startups sukses mengubah ide-ide mereka secara fundamental, yang sering dikenal sebagai pivot. Youtube sempat menjadi web layanan perjodohan dan kencan. Instagram digagas awal sebagai layanan lokasi. Mereka contoh bagaimana bisnis harus open mind untuk segala kemungkinan, belajar dari kebutuhan pengguna.

5. Lebih baik untuk melayani beberapa pengguna yang bahagia, daripada banyak namun tak acuh

Jika Anda bertanya kepada orang-orang, apakah mereka suka dengan bisnis startup Anda, kemungkinan besar mereka akan mengatakan "ya" . Acapkali orang-orang tidak tega membunuh impian dan pekerjaan orang. Tapi itu tidak ada artinya bagi Anda. Biarkan mereka memilih dengan bukti waktu dan uang mereka. Jika mereka benar-benar menggunakan jasa atau produk Anda, itulah itu yang penting anda kejar. Jika mereka mengatakan bisnis anda sebagai ide yang bagus tapi tidak menggunakan Anda, Anda perlu khawatir.

\section{Kejutkan pelanggan dengan layanan anda}

Anda dapat untuk berbicara langsung dengan pelanggan via telepon atau secara pribadi pada awal bsinis. Kenapa tidak? Mereka adalah orang-orang pertama yang menemukan dan menikmati manfaat produk Anda. Belajar dari mereka, temukan apa yang mereka butuhkan, dan berikan solusi yang terbaik untuk mereka dari apa yang anda miliki melalui produkatau jasa.

\section{Anda memproduksi sesuatu yang bisa Anda ukur}

Anda bukan bisnis startup jika anda tidak tumbuh. Meskipun angka pertumbuhan sering menipu jika Anda menggunakan metrik yang kurang tepat. Dalam bisnis, sering cuma ada dua pilihan yaitu tumbuh atau mati. Kenapa harus 
tumbuh?. Karena setiap hari persaingan bisnis kian meningkat dan beban bisnis semakin bertambah.

\section{Berhematlah}

Tidak peduli berapa banyak dana yang Anda miliki, Anda selalu lebih dekat dengan kematian dari yang Anda pikirkan. Uang investor Anda adalah uang yang Anda tidak benar-benar anda miliki. Hanya gunakan uang yang dapat meningkatkan nilai bisnis anda. Jika anggaran terbatas, sewa gedung terkadang lebih baik daripada beli gedung.

\section{Dapatkan keuntungan mie instan}

Jika Anda memiliki sedikit pemasukan uang, itu tetap berarti. Karena ada beberapa orang yang menghargai produk atau jasa Anda dan bersedia untuk membayarnya. Itu adalah tanda utama bahwa perusahaan Anda mungkin bisa bertahan hidup. Sekarang hanya soal mendapatkan lebih banyak pelanggan untuk melakukan hal yang sama.

\section{Menghindari gangguan}

Satu-satu alasan utama lahirnya bisnis startup adalah untuk melayani penggunanya. Mencari pendanaan, sekolah lanjut, pamer di sosial media, dan lomba bisnis bisa jadi pengalih perhatian. Hal tersebut mungkin juga berguna selama mereka tetap prioritas meluangkan waktu dan perhatian dari membangun produkatau jasa bisnis startup.

\section{Jangan demoralisasi}

Dalam startup tidak akan terjadi apa-apa, sampai Anda yang mewujudkannya. Orang tidak akan otomatis merespon. Pelanggan akan mencoba untuk tidak membayar. Mitra tidak akan tiba-tiba datang. Investor akan berlalu begitu saja. Karyawan akan keluar-masuk. Apa yang bisa kau lakukan? Anda tidak boleh pergi begitu saja. Anda perlu terus berjalan dengan susah payah menjalaninya, sampai Anda menemukan apa yang pengguna butuhkan, dikenal dan dipercaya.

\section{Jangan menyerah}

Cara pasti untuk membuat orang percaya dengan bisnis startup anda adalah dengan terus tumbuh dan berkembang. Jika Anda tidak bisa tumbuh, maka teruslah berjalan. Saat Anda menyerah, ya sudah, itu benar-benar berakhir dalam bisnis startup anda. Ingatlah, kesulitan yang anda hadapi juga dihadapi 
semua bisnis startup. Yang membedakan, ada yang jalur bertahan dan terus berjalan, dan ada yang jalur menyerah. Anda tinggal memilih jalur yang mana.

\section{Siap dengan Kondisi Terburuk}

Mungkin sulit untuk percaya, tetapi bahkan setelah investor mengatakan "ya" , mereka mungkin masih belum pernah mengirimkan cek kepada anda. Konsumen tiba-tiba menghilang dan tidak membayar anda. Supplier bisa tidak mengirim pesanan anda tepat waktu.

\section{Teruslah melangkah}

Kesuksesan para pebisnis yang anda lihat sekarang adalah hasil setiap langkah yang mereka jalani. Baik ketika kondisi berat maupun kondisi bisnis begitu menguntungkan. Teruslah melangkah, kadang kita tak tahu pada langkah keberapa kita tersandung batu yang berkilau ternyata emas atau intan permata.

\section{Penutup}

Demikianlah beberapa tips agar pengusaha dapat bertahan di dunia bisnis secara konsep dan aplikatif.

\section{References}

Anna Vital. 2015. The 13 Startup Survival Rules.

http://fundersandfounders.com/13-startup-survival-rules/

Paul Graham. 2009. Startups in 13 Sentence.

http://www.paulgraham.com/13sentences.html 